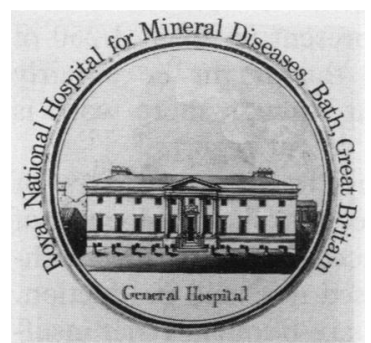

The typical case of gout is easy to recognise: a middle aged man, overweight and full of bonhomie, high facial colouring, and overfond of food and alcohol, he presents with an excruciatingly painful, hot, red toe and demands treatment. Management of such cases is usually straightforward. It is arguably more important for the doctor to be on the lookout for the associations of gout than it is to treat the arthritis in such patients. Obesity, hyperlipidaemia, hypertension, a high alcohol intake, and preventable cardiovascular disease are all associated, and the gout should act as a 'signal' for the need to remove as many cardiovascular risk factors as possible.

This article, however, focuses on the young and the elderly with gout as they pose different and difficult management problems. Gout is unusual in the young and particularly so in women before the menopause, a fact that was recognised by Hippocrates. ${ }^{1}$ Onset before the age of 30 in a man and in any premenopausal woman should raise the question of a specific enzyme defect leading to marked purine overproduction or an inherited defect in renal tubular handling. Early identification of these cases is important because treatment may ameliorate complications such as urate calculi and renal damage. The elderly with gout are also a special group. Here, the presentation is often atypical and drug treatment presents special difficulties. Severe side effects to both non-steroidal anti-inflammatory agents and to allopurinol are common in this group.

Investigating gout in the young A white man, born May 1958, had his first episode of acute gout at the age of 27. During the next four years he had about two attacks of gout a year. He has a family history of gout, his grandfather and one brother being affected. There is no history of renal calculi, alcohol excess, or exposure to lead. On examination he was not obese, there were no tophi, and he was normotensive. A full blood count was normal, as were the urea and electrolytes and liver function tests. The creatinine clearance was 94 $\mathrm{ml} / \mathrm{min}$. The fasting serum triglyceride concentration was $3.9 \mathrm{mmol} / \mathrm{l}$ (normal value $0.5-1 \cdot 7$ ). Serum uric acid concentration was $0.52 \mathrm{mmol} / \mathrm{l}$ (fluorimetric method). The urea/creatinine ratio on a spot urine was normal at 0.38 . The 24 hour uric acid excretion after five days on a low purine diet was $4 \cdot 1 \mathrm{mmol}$, however, indicating relative overproduction; most idiopathic gout in young men is associated with mild undersecretion of uric acid. Erythrocyte purine enzyme activity measured by high performance liquid chromatography was normal. Partial aldolase- $\beta$ deficiency was detected by ${ }^{31} \mathbf{P}$ magnetic resonance spectroscopy. His diet was changed to lower the serum triglyceride concentration to normal. His uric acid was normalised with allopurinol (300 $\mathrm{mg}$ daily), and he is now free from gout.

Table 1 outlines a plan for investigation of young male patients and premenopausal women with gout. It is important to exclude underlying conditions. A proportion will be shown to have one of the specific abnormalities shown in the table. Other conditions not commonly encountered include glucose-6-phosphatase deficiency, ${ }^{2}$ compensated chronic haemolytic anaemia, ${ }^{3}$ other endogenous causes of accelerated

Table 1 Plan of investigation for patients with early onset of gout

\begin{tabular}{|c|c|c|c|c|}
\hline \multirow[t]{2}{*}{ Investigation } & \multicolumn{3}{|l|}{ Over producers } & \multirow{2}{*}{$\begin{array}{l}\text { Undersecretors } \\
\text { Precocious } \\
\text { familial gout } \\
\text { (with or without } \\
\text { renal disease) }\end{array}$} \\
\hline & $\begin{array}{l}\text { HGPRT* } \\
\text { deficiency }\end{array}$ & $\begin{array}{l}\text { PRPP* synthetase } \\
\text { overactivity }\end{array}$ & $\begin{array}{l}\text { Aldolase- } \beta \\
\text { deficiency }\end{array}$ & \\
\hline 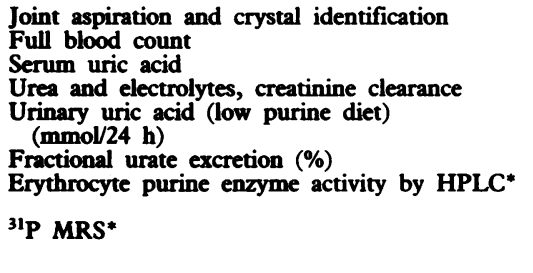 & $\begin{array}{l}\uparrow \\
\text { Normal } \\
>3.6 \\
\text { Partial HGPRT } \\
\text { deficiency }\end{array}$ & $\begin{array}{l}\uparrow \\
\text { Normal } \\
>3 \cdot 6 \\
\text { Increased PRPP } \\
\text { synthetase activity }\end{array}$ & $\begin{array}{l}\text { Partial aldolase- } \beta \\
\text { deficiency }\end{array}$ & $\begin{array}{l}\uparrow \\
\text { May be normal } \\
<1 \cdot 8 \\
<7\end{array}$ \\
\hline
\end{tabular}

'HGPRT=hypoxanthine-guanine phosphoribosyltransferase; PRPP=5'-phosphoribosyl-1-pyrophosphate; HPLC=high performance liquid chromatography; MRS=magnetic resonance spectroscopy. 
ATP metabolism ${ }^{4}$ exposure to factors such as lead, which interfere with urate excretion, and renal disorders such as medullary cystic disease, ${ }^{5}$ Bartter's syndrome, and Alport's syndrome.

A much higher incidence of family history of gout occurs in patients with early onset: over $50 \%$ with onset under the age of 25 have a positive family history and over $80 \%$ with onset between 12 and $19 .^{6}$ The frequency of gouty attacks is often high, and urolithiasis may be a prominent feature. On the other hand, cardiovascular risk factors commonly associated with 'typical' gout occur less commonly, though they should still be looked for, as in the older patient.

In the young it is advisable to confirm the diagnosis of acute gout by joint aspiration and crystal identification. The principal differential diagnosis in this age group is psoriatic or reactive arthritis, though other crystalline arthropathies, haemarthrosis, and septic arthritis may occasionally simulate gout in young people.

The serum uric acid concentration is invariably raised above normal. A full blood count to exclude haemolytic anaemia or other haematological disorders, and simple tests of renal function should be performed in all cases. The 24 hour uric acid excretion value on a normal diet or estimation of the uric acid/creatinine ratio, or both, can be used as simple screening tests for marked overproducers and undersecretors of uric acid. Excretion of uric acid greater than $6 \mathrm{mmol} / 24 \mathrm{~h}$ and a ratio of 0.8 indicate overproducers. More detailed investigation is generally required, however. As illustrated in the patient described here the uric acid/creatinine ratio can be unreliable. ${ }^{7}$

When possible, patients should be placed on a low purine, caffeine free, alcohol free diet for five days and drugs influencing uric acid production and excretion discontinued. A 24 hour uric acid excretion greater than $3.6 \mathrm{mmol}$ indicates overproduction. Undersecretion can be determined by evaluating urate clearance in relation to creatinine clearance. Values less than $7 \%$ indicate undersecretion. $^{8}$

A proportion of these patients, probably no more than $20 \%$, will have overproduction of uric acid and, in a minority of these, abnormal purine enzyme activity can be identified. Purine enzyme activity can be assessed in erythrocytes, B lymphoblasts, or fibroblasts by high performance liquid chromatography. ${ }^{9}$

Complete deficiency of hypoxanthine-guanine phosphoribosyltransferase occurs in the LeschNyhan syndrome, ${ }^{10}$ but partial deficiency (referred to as the Kelley-Seegmiller syndrome) or increased 5'-phosphoribosyl-1-pyrophosphate synthetase activity is associated with gout in adolescents and young adults, often accompanied by urolithiasis. ${ }^{11} 12$ Genetic transmission is $\mathrm{X}$ linked in both cases and gene studies show various genetic mutations in different kindreds. ${ }^{13}$ If abnormalities are found family studies and detection of heterozygotes should be considered.

Recently, early onset gout has been associated with partial deficiency of aldolase- $\beta .{ }^{14}$ The case described here is an example. Heterozygotes for this enzyme deficiency can be shown by ${ }^{31} \mathrm{P}$ magnetic resonance spectroscopy of the liver after a small dose of oral fructose. The test dose may also produce a significantly larger increment in the concentration of serum urate than in unaffected family members. As the heterozygous state may be present in about $1 / 250$ of the white population this might be a fairly common cause of gout, though more work is needed to confirm the recent report.

In some series ${ }^{15}$ up to three quarters of patients with early onset gout, including most of the women, have reduced urate clearance without evidence of increased uric acid production. Characteristic features are frequent renal insufficiency, which bears no clear relation to the hyperuricaemia, and a strong family history with some members dying of premature renal failure. Early identification of these patients together with asymptomatic but affected family members is essential because allopurinol may ameliorate the renal damage. ${ }^{16}$ Again, identification of cases should be followed by family studies.

\section{Managing gout in the elderly}

Two white women first developed signs of gout at the ages of 70 and 79 respectively. In both cases these consisted of tophi developing over Heberden's nodes (fig 1). After seven years patient No 1 developed acute gout of the second and third metacarpophalangeal joints of the left hand. Aspiration showed urate crystals. Patient No 2 never developed acute gout, but the tophaceous deposits progressively enlarged in the periarticular regions of both hands and feet and in the pulp of the digits, where they were painful. Radiographic changes were noted (figs 2 and 3 ). Both patients had heart disease and had been receiving long term diuretics. Neither was obese nor hypertensive, there was no family history of gout, and there was no alcohol abuse. The serum uric acid concentration was 0.62 and $0.71 \mathrm{mmol} / \mathrm{l}$, respectively. The full blood count was normal. Patient 2, but not patient 1 , had evidence of renal insufficiency (urea 18.6 $\mathrm{mmol} / \mathrm{l}$ ). The acute arthritis of patient 1 responded rapidly to indomethacin $50 \mathrm{mg}$ three

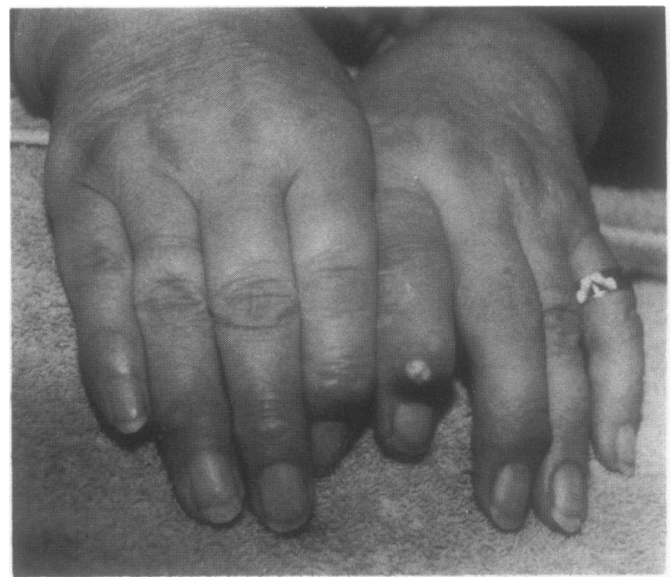

Figure 1 Gouty tophus overlying a Heberden's node on the index finger of patient No 1 . 


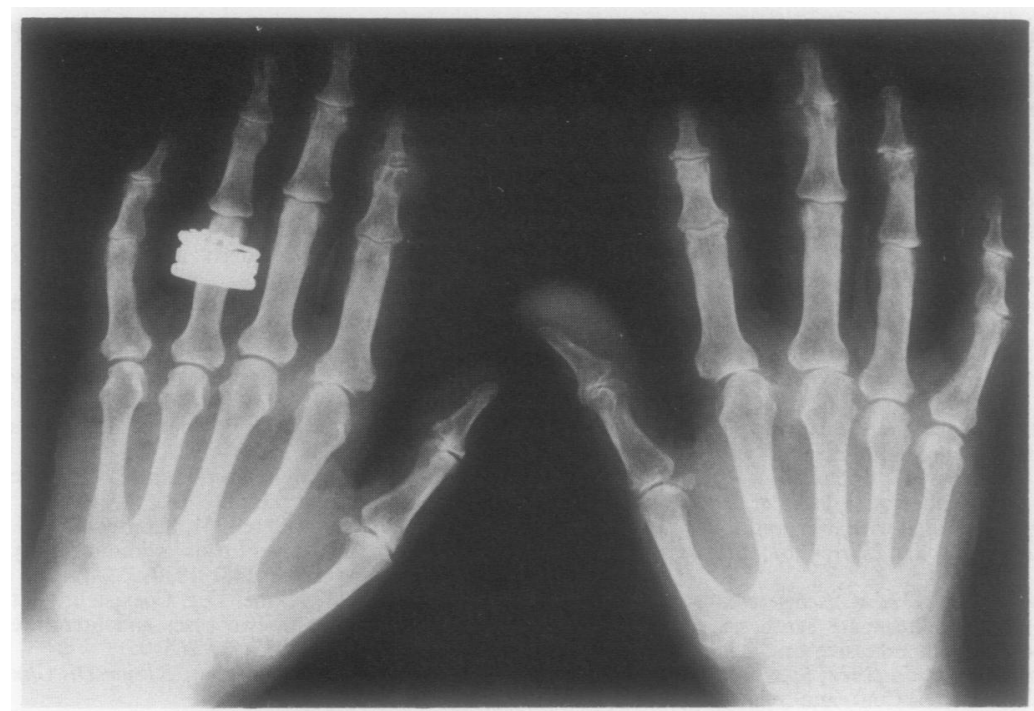

Figure 2 Plain radiograph of hands of patient No 2 showing nodular soft tissue masses due to tophi and typical punched out erosions.

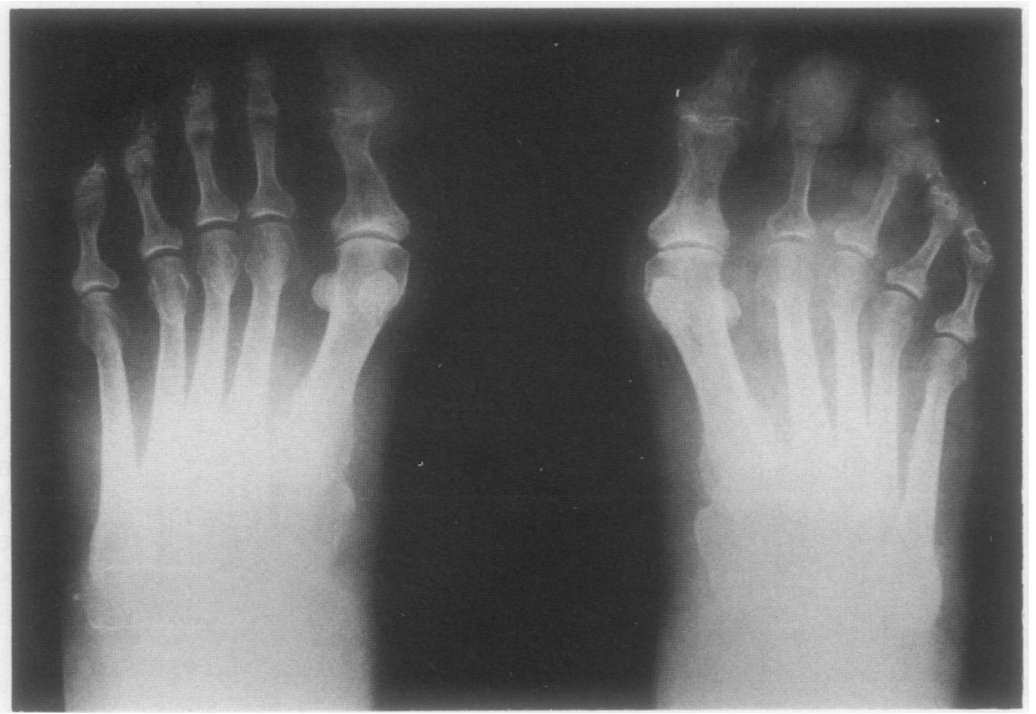

Figure 3 Development of tophi in the pulps of the digits in patient No 2 is associated with progressive destruction of the phalanges.

times a day. The diuretic was discontinued without the development of heart failure. Allopurinol $100 \mathrm{mg} /$ day was started after resolution of acute gout. The uric acid concentration returned to normal. Management of the gout in patient 2 was a much greater problem, however. It was not possible to stop the diuretic because of severe cardiac failure. Furthermore, a variety of non-steroidal anti-inflammatory drugs produced severe gastrointestinal symptoms, as did low dose oral colchicine. The tophi remain painful and have developed secondary sepsis, and radiographic damage is progressing. Treatment has been started with low dose allopurinol (100 $\mathrm{mg}$ alternate days).

Gout is an increasingly recognised problem in the elderly. ${ }^{17}$ It occurs mainly in women and the chief risk factors seem to be diuretics ${ }^{18}$ and renal disease. ${ }^{19}$ The risk factors associated with typical gout in the middle aged man are usually absent. The presentation is also typical as there are few, if any, acute attacks and tophi commonly develop. The tophi are particularly likely

\section{Table 2 Management of gout in the elderly}

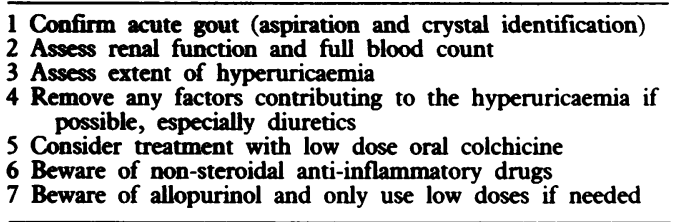

to occur in Heberden's nodes ${ }^{20}$ and the pulps of the fingers. ${ }^{22}$

The difficulty in this group is not diagnosis, but management. The appearance of the tophi usually makes the diagnosis obvious, though confusion with septic arthritis can occur, and one must be wary of coexistent sepsis. ${ }^{23}$ Management is made difficult by the high risk of drug side effects. Table 2 indicates an approach to the management of these patients. Aspiration and crystal identification to confirm acute gout are advisable and may be necessary to exclude infection. The degree of hyperuricaemia should be measured and renal function assessed, but further complex investigations are generally unnecessary.

The first step in management is to see whether any predisposing factors are avoidable. For example, diuretic treatment may be unnecessary, and alcohol may be being abused. The second step is to decide whether any drugs are needed. Often they are not, and arguably the gout in patient 1 might have been managed without any specific treatment. Painful ulcerating lesions, tissue destruction, and a risk of hyperuricaemia causing accelerated renal damage may all indicate the need for treatment, however.

Painful inflammation is probably best treated with low dose colchicine $(0.5 \mathrm{mg}$ twice a day), which rarely causes problems. Non-steroidal anti-inflammatory drugs are dangerous, not only because of their gastroenterological and neurological side effects in this group but also because of their nephrotoxicity potential and potentiation of fluid retention. Allopurinol is also dangerous. Toxicity to this drug increases with age and is enhanced by renal insufficiency and concurrent diuretic treatment. ${ }^{24}$ In addition to rashes, a generalised hypersensitivity reaction can occur with features such as vasculitis, hepatitis, cytopenia, acute intestinal nephritis, and toxic epidermal necrolysis. ${ }^{25} 26$ This can be fatal. If the drug is used at all it should be in low doses, perhaps starting with $100 \mathrm{mg}$ on alternate days. Uricosuric drugs are generally ineffective in this group of patients.

In general, extreme caution should be exercised when attempting to treat the elderly patient with tophaceous gout.

1 Hippocrates. The gemuine works of Hippocrates. Vols I and II. New York: Wood, 1886. (Translated from the Greek with a New York: Wood, 1886. (Translated from the Greek with a preliminary discourse and annotation by Francis Adams.)
Wyngaarden \& B, Kelley W N. Gout. In: Stanbury J B, Friedriekseh D A, Goldstein J L, Brown M S, eds. The metabolic basis of inherited disease. 5th ed. New York: McGraw-Hill, 1983: 1043-114.

3 Liberman U A, Samuel R, Halabe A, Sperling O. Juvenile gout and hyperuricosuria due to chronic compensated haemolytic syndrome. Fortschritte der Urologie und Nephrologie 1981; 16: 32-5.

4 Fox I H, Palella T D, Kelley $W$ N. Hyperuricaemia: a 
marker of cell energy crisis. $N$ Engl $\mathcal{F}$ Med 1987; 317: 111-2.

5 Thompson G R, Weiss J J, Goldman R T, Rigg G A. Familial occurrence of hyperuricaemia, gout and medullary cystic disease. Arch Intern Med 1978; 138: 1614-7.

6 Yu T-F. Diversity of clinical features in gouty arthritis. Semin Arthritis Rhewe 1984; 13: 360-8.

7 Wortmann R L, Fox I H. Limited value of uric acid to creatinine ratios in estimating uric acid excretion. Am creatinine ratios in estimating

8 Gibson T, Highton J, Simmonds H A, Potter C F. Hypertension, renal function and gout. Postgrad Med $\dot{j}$ 1979; 55 (suppl 3): 21-5.

9 Roylance H J, Wallace R C, Nuki G. Inborn errors of purine metabolism in men: development of purine enzyme assays using HPLC. Ann Rheum Dis 1983; 42 (suppl): 86.

10 Seegmiller J E, Rosenbloom E M, Kelley W N. An enzyme defect associated with sex-linked neurological disorder and excessive purine synthesis. Science 1967; 155: 561-7.

11 Kelley $W \mathrm{~N}$, Rosenbloom E M, Henderson J F, et al. A specific enzyme defect in gout associated with overproducspecific enzyme defect in gout associated with overproduction of thic

12 Sperling O, Eilam G, Persky-Brosh S N, et al. Accelerated erythrocyte 5'-phosphoribosyl-1-pyrophosphate synthesis. A familial abnormality associated with excessive uric acid production and gout. Biochemical Medicine 1972; 6: 310-5.
Kelley W N, Fox I H, Palella T D. Gout and related Kelley W N, Fox I H, Palella T D. Gout and related E D, Ruddy S, Sledge C B, eds. Textbook of rheumatology. 3rd ed. Philadelphia: Saunders, 1989: 1395-448.

14 Seegmiller J E, McAlindon T, Dieppe P, et al. An aberration of fructose metabolism in familial gout identified by ${ }^{31} \mathrm{P}$ 政 15 Calabrese G, Simmonds H A, Cameron J S, Davies P M. Precocious familal gout with reduced fractional urate clearance and normal purine enzymes. $Q \mathcal{f}$ Med 1990; 75 :

Simmonds H A, Cameron I S, Potter C F, Farebrother D A Gout and renal failure in young women. Clin Nephrol 1980; 14: 176-88.

17 Borg E J J, Rasher J J. Gout in the elderly: a separate entity? Ann Rheum Dis 1987; 46: 72-6.

18 Macfarlane D G, Dieppe P A. Diuretic-induced gout in elderly women. $\mathrm{Br} \mathcal{F}$ Rheumatol 1985; 24: 155-7.

19 Hollingworth P, Scott J T, Burry H C. Non-articular gout hyperuricaemia and tophus formation without gouty arthritis. Arthritis Rheum 1983; 26: 98-101.

20 Simkin P A, Campbell P M, Larson E B. Gout in Heberden's nodes. Arthritis Rheum 1983; 26: 94-7.

21 Doherty M, Dieppe P. Crystal deposition disease in the elderly. Clin Rheum Dis 1986; 12: 97-116.

22 Shimerling R H, Stern S H, Gravallese E M, Kantrowitz F G. Tophacious deposition in finger pads without gouty Tophacious deposition in finger pads without
arthritis. Arch Intern Med 1988; 148: 1830-2.

23 O'Connell P G, Milburn B M, Nashel D J. Coexistent gout and septic arthritis: a report of two cases and literature and septic arthritis: a report of two cases and

24 Wallace S L, Singer J Z. Therapy in gout. Rheum Dis Clin North Am 1988; 14: 441-57.

25 Singer J Z, Wallace S L. The allopurinol hypersensitivity problem. Arthritis Rheum 1986; 29: 82-9.

26 Emmerson B T. Hyperuricaemia and gout in clinical practice. ADIS Health Science Press, 1983. 